\title{
Tularemi Lenfadeniti Şüphesi ile Alınan Lenf Aspiratı Örneklerinde Mycobacterium tuberculosis Varlığının Araştırılması
}

\author{
Investigation of the Presence of Mycobacterium tuberculosis \\ in the Lymph Node Aspirates of the Suspected Tularemia \\ Lymphadenitis Cases
}

\author{
Nurhan ALBAYRAK ${ }^{1}$, Bekir ÇELEBi ${ }^{2}$, Semra KAVAS ${ }^{1}$, Hülya şiMŞEK ${ }^{1}$, Selçuk KILIÇ², \\ Figen SEZEN ${ }^{1}$, Ahmet ARSLANTÜRK ${ }^{1}$

\footnotetext{
${ }^{1}$ Türkiye Halk Sağlığı Kurumu, Ulusal Tüberküloz Referans Laboratuvarı, Ankara.

${ }^{1}$ Public Health Institution of Turkey, National Tuberculosis Reference Laboratory, Ankara, Turkey.

${ }^{2}$ Türkiye Halk Sağlığı Kurumu,Ulusal Tularemi Referans Laboratuvarı, Ankara.

2 Public Health Institution of Turkey, National Tularemia Reference Laboratory, Ankara, Turkey.
}

Geliş Tarihi (Received): 17.12.2012 • Kabul Ediliş Tarihi (Accepted): 13.08.2013

ÖZET

Servikal lenfadenitin en sık karşılaşılan granülomatöz enfeksiyöz etkenleri olan tüberküloz lenfadeniti ve orofarengeal tularemi bildirimleri ülkemizde son yıllarda belirgin olarak artmaya başlamıştır. Her iki lenfadenit etkeni de klinik ve histopatolojik olarak birbirleriyle karışabilmektedir. Bu nedenle tularemin endemik olduğu bölgelerde, tanıda tüberküloz geri planda kalmakta ve hastalar tularemi lenfadeniti açısından incelemeye alınmaktadır. Bu çalışmada, tularemi lenfadeniti şüphesiyle laboratuvarımıza gönderilen servikal lenf aspiratı örneklerinde, Mycobacterium tuberculosis varlığının araştırılması amaçlanmıştır. Çalışmaya, 2009-2011 yılları arasında Türkiye Halk Sağlığı Kurumu Ulusal Tularemi Laboratuvarına, orofarengeal tularemi şüphesiyle gönderilen ve tularemi açısından bakteriyolojik (kültür), moleküler (PCR) ve serolojik (mikroaglütinasyon) yöntemlerle negatif olarak bulunan 105 hasta dahil edilmiştir. Hastalara ait lenf aspiratı örnekleri, Ulusal Tüberküloz Laboratuvarında M.tuberculosis açısından kültür ve gerçek zamanlı PCR (rtPCR) yöntemleri ile incelenmiştir. Mikobakteri kültürü hem Löwenstein-Jensen (LJ) besiyerinde hem de sıvı bazlı MGIT (BD, $A B D)$ otomatize kültür sisteminde yapılmıştır. Üreme tespit edilen örnekler immünokromotografik test $(B D, A B D)$ ile M.tuberculosis olarak tanımlanmıştır. Çalışmada kontrol grubu olarak, F.tularensis antikorları pozitif olarak bulunan 65 hastanın, F.tularensis PCR'ı negatif lenf aspiratı örnekleri kullanılmıştır. Farklı coğrafik bölgelerden laboratuvarımıza tularemi araştıııması amacıyla gönderilen ve negatif bulunan hastalara ait 105 lenf aspiratı örneğinin 9 (\%8.6)'u M.tuberculosis pozitif olarak saptanmıştır. M.tuberculosis saptanan olguların altısının erkek olduğu ve yaş dağılımının 26-85 yıl arasında değiş̧tiği belirlenmiş̧tir. M.tuberculosis varlığı, örneklerin ikisinde sadece kültür, beşin- 
de sadece rtPCR ve ikisinde hem kültür hem de rtPCR ile gösterilmiştir. Kontrol grubu örneklerinde M.tuberculosis tespit edilmemiştir. M.tuberculosis saptanan dokuz örneğin üçünün tulareminin endemik olduğu bölgeden gelen örnekler olduğu izlenmiştir. Sonuç olarak bu ön çalışmanın verileri, tularemin endemik olduğu bölgelerde tularemi lenfadenitinden şüphelenilen olgularda, tüberküloz lenfadenitinin de akılda tutulması gerektiğini ortaya koymuş ve bu olguların eş zamanlı olarak M.tuberculosis yönünden de araştırılmasının uygun olacağını düşündürmüştür.

Anahtar sözcükler: Lenfadenit; tüberküloz; tularemi; kültür; gerçek zamanlı PCR.

\section{ABSTRACT}

Recently reports of cervical tuberculous lymphadenitis and oropharyngeal tularemia which are the most common infectious causes of granulomatous lymphadenitis, have been significantly increased in Turkey. The differentiation of cervical tuberculous lymphadenitis and oropharyngeal tularemia is usually confusing on the basis of clinical and histopathological findings. Thus, in tularemia endemic areas, the patients are more commonly evaluated in terms of tularemia lymphadenitis leaving tuberculosis out. The aim of this study was to investigate the presence of Mycobacterium tuberculosis in cervical lymph node aspirates, obtained from tularemia suspected cases. A total of 105 oropharyngeal tularemia-suspected cases which were found negative for Francisella tularensis by bacteriological (culture), molecular (PCR) and serological (microagglutination) methods, were included in the study. The samples had been previously studied at National Tularemia Reference Laboratory, Turkish Public Health Institution, between 2009-2011. The study samples were evaluated in terms of M.tuberculosis by culture and real-time PCR (rtPCR) methods in the National Tuberculosis Reference Laboratory. Both Lowenstein-Jensen (LJ) medium and liquid-based MGIT (BD, USA) automated culture system were used for mycobacterial culture. Samples that yielded mycobacterial growth were identified as M.tuberculosis by immunochromotographic test (BD, USA). The lymph node aspirates of 65 patients who were F.tularensis PCR negative but antibody positive, were used as the control group. As a result, M.tuberculosis was found to be positive in $9(8.6 \%)$ of 105 tularemia-negative lymph node aspirates, sent to our laboratory from different geographic regions for the investigation of tularemia. Six of the M.tuberculosis positive cases were male and the age range of the patients was 26-85 years. The presence of M.tuberculosis was detected only by culture in two samples, only by rtPCR in five samples and both by culture and rtPCR in two samples. M.tuberculosis was not identified in the control group specimens. Three of the samples which revealed tuberculosis, were from the tularemia endemic areas. In conclusion, the data of this preliminary study indicated that tuberculous lymphadenitis should be kept in mind in suspected tularemia cases and those patients should also be investigated simultaneously for the presence of tuberculous lymphadenitis.

Key words: Lymphadenitis; tuberculosis; tularemia; culture; real-time PCR.

\section{Giriş̧}

Tüberküloz (TB), tüm dünyada ve ülkemizde halen ciddi bir halk sağlığı sorunu olarak önemini korumaktadır ${ }^{1,2}$. Esas olarak akciğerleri tutmakla birlikte, Mycobacterium tuberculosis, primer enfeksiyon sırasında lenfo-hematojen ve direkt yayılımla akciğer dışı organları da etkileyebilir. TB lenfadenit, lenf drenajına uygun olarak, çoğunlukla servikal ve supraklaviküler lenf bezlerini tutmaktadır. TB lenfadenit, sistemik TB ile beraber veya tek başına bir klinik bulgu olarak görülebilir ${ }^{3,4}$. Akciğer dışı tüberküloz (AD-TB), dünyada tüm TB olgularının \%15'ini oluşturmakta; ülkemizde ise bu oran 2007 yılı için \%30.5 (6004/19.694) olarak bildirilmekte ve en sık görülen formların sırasıyla plevra (\%38.3), 
ekstratorasik lenfadenit (\%28.6) ve intratorasik lenfadenit (\%4.8) olduğu belirtilmektedir $^{1-3}$. Bu verilere göre ülkemizde yılda 1600-2000 arasında TB lenfadenit olgusu tanımlanmaktadır².

Francisella tularensis'in etken olduğu tularemi, son yıllarda ülkemizde oluşan salgınlar ile yeniden önem kazanmıştır ${ }^{5}$. Tularemide klinik tablo; etkenin konağa giriş yoluna göre ülseroglandüler, glandüler, oküloglandüler, orofarengeal, respiratuvar ya da tifoidal olmak üzere altı ana formda görülmektedir ${ }^{6,7}$. Ülkemizde klorlanmamış içme suyu tüketimine bağlı olarak en sık orofarengeal form (farenjit veya tonsillit ile servikal lenfadenopati) ortaya çıkmaktadır. Bu formun seyrinde bölgesel lenfadenopati (LAP) en önemli klinik belirtilerden birisidir ${ }^{5}$. Orofarengeal tularemi formunda farenjiti takiben gelişen servikal LAP, bazı olgularda klinik ve histopatolojik görünüm (granülomatöz inflamasyon ve kazeifikasyon nekrozu) nedeniyle servikal TB lenfadenit tanısının konulmasına neden olmaktadı ${ }^{5,8}$. Ancak tulareminin endemik olduğu bölgelerde farkındalığın artması, servikal bölgedeki lenfadenitlerde, tanıda tulareminin ilk planda düşünülmesiyle sonuçlanmıştır. Servikal TB lenfadenit tanısı alan hastalarda tulareminin rolü araştırılmış olmasına rağmen, her iki etken açısından da endemik olan ülkemizde orofarengeal tularemi ön tanısı nedeniyle alınan örneklerde TB lenfadenitine yönelik herhangi bir çalışma henüz yapılmamıştır. Bu çalışmada, 2009-2011 yılları arasında Türkiye Halk Sağlığı Kurumu Ulusal Tularemi Laboratuvarına, tularemi lenfadeniti şüphesiyle gönderilen servikal bölge lenf aspiratı örneklerinde M.tuberculosis varlığı ve sıklığının araştırılması amaçlanmıştır.

\section{GEREÇ ve YÖNTEM}

Çalışmaya, ülkemizin farklı coğrafi bölgelerinden, Türkiye Halk Sağlığı Kurumu Ulusal Tularemi Laboratuvarına orofarengeal ve glandüler tularemi şüphesi ile gönderilen ve bakteriyolojik, moleküler ve serolojik yöntemlerle tularemi açısından negatif bulunan 105 hasta örneği dahil edildi. Bakteriyolojik incelemede, hastaların lenf aspiratı örnekleri \%10 koyun kanlı sistein kalp agar besiyerine $(\mathrm{CHAB})$ ekildi ve $\% 5 \mathrm{CO}_{2}{ }^{\prime}$ li ortamda $37^{\circ} \mathrm{C}^{\prime}$ de 10 gün inkübe edildi. Moleküler incelemede, lenf aspiratı örneklerinde F.tularensis DNA'sı konvansiyonel PCR yöntemiyle araştırıldı. Bu yöntemde DNA ekstraksiyonu, QIAamp DNA mini kit (Qiagen, Almanya) ile yapıldı ve 17 kDa membran proteinini kodlayan tul4 genini hedefleyen primerler kullanıldı. Serolojik inceleme ise hastalara ait serum örneklerinde mikroaglütinasyon testiyle $F$. tularensis antikorlarının araştırılmasıyla gerçekleştirildi ${ }^{9}$.

Bakteriyolojik, moleküler ve serolojik yöntemlerle negatif bulunan 105 örnek, Türkiye Halk Sağlığı Kurumu Ulusal Tüberküloz Laboratuvarında M.tuberculosis varlığı açısından incelendi.

Lenf aspiratı örnekleri, $\mathrm{NaOH}-\mathrm{NALC}$ yöntemiyle homojenizasyon-dekontaminasyonkonsantrasyon (HDK) işlemine alındı. Takiben, kültür için hem Löwenstein-Jensen (LJ) (BBL Mycobactosel L-J Medium, BD, ABD) besiyerine hem de sıvı bazlı MGIT (BD, ABD) otomatize kültür sistemine ekim yapıldı. LJ besiyerleri 8 hafta, MGIT besiyerleri ise 6 
hafta boyunca $37^{\circ} \mathrm{C}^{\prime}$ de inkübe edildi. Besiyerlerinin haftalık üreme kontrolleri yapıldı; üreme tespit edilen örnekler Ehrlich-Ziehl-Neelsen boyama yöntemi ile aside dirençli bakteri (ARB) varlığı açısından değerlendirildi. ARB pozitif bulunan örnekler immünokromotografik test (BD, $A B D)$ ile doğrulamaya alındı. HDK işlemi yapılan tüm örnekler M.tuberculosis varlığı açısından ayrıca gerçek zamanlı PCR (rtPCR) testi ile araştırıldı. HDK işlemine alınan örneklerden bakteri DNA'sı, QiaAMP DNA Mini kiti (Qiagen, Almanya) ile EZ1 (Qiagen, Almanya) cihazında ekstrakte edildikten sonra, M.tuberculosis PCR kiti (The Artus ${ }^{\circledR}$ M.tuberculosis RG PCR Kit, Qiagen, Almanya) ile Rotorgene 600 cihazında amplifiye edildi. F.tularensis antikorları pozitif bulunan 65 hastanın, PCR ile F.tularensis negatif bulunan lenf aspiratı örnekleri çalışmada kontrol grubu olarak kullanıldı.

\section{BULGULAR}

Çalışmamızda, tularemi araştırılması amacıyla laboratuvarımıza gönderilen ve F.tularensis yönünden negatif bulunan 105 lenf aspiratı örneğinin 9 (\%8.6)'u, rtPCR ve/veya kültür yöntemi ile M.tuberculosis pozitif olarak saptanmıştır. Bu örneklerin 2'si hem kültür hem rtPCR ile, 2'si sadece kültür ile, 5'i ise sadece rtPCR ile pozitif olarak bulunmuştur (Tablo I). Kültürde üreyen örneklerden 3'ü hem LJ hem de MGIT besiyerinde pozitif olarak saptanırken, bir örneğe ait üreme sadece LJ besiyerinde tespit edilmiştir. Tularemi serolojisi açısından pozitif bulunan kontrol grubu örneklerinde $(n=65)$ M.tuberculosis tespit edilmemiştir. M.tuberculosis pozitif 9 örnekten 3'ünün, tulareminin en sık görüldüğü Yozgat ilinden gelen örnekler olduğu izlenmiştir (Tablo I).

\section{TARTIŞMA}

M.tuberculosis ve F.tularensis, servikal lenfadenitlerin granülomatöz reaksiyon oluşturan enfeksiyöz etkenlerinden en önemlileri arasında yer almaktadır. Bu infeksiyöz etkenlerden M.tuberculosis süpüratif olmayan, F.tularensis ise sıklıkla süpüratif servikal

\begin{tabular}{|c|c|c|c|c|c|}
\hline \multirow[b]{2}{*}{ Örnek no } & \multirow[b]{2}{*}{ Cinsiyet } & \multirow[b]{2}{*}{ Yaş (Yıl) } & \multirow[b]{2}{*}{ Gönderildiği il } & \multicolumn{2}{|c|}{ M.tuberculosis } \\
\hline & & & & Kültür & rtPCR \\
\hline 1 & $E$ & 52 & Adana & $(+)$ & $(-)$ \\
\hline 5 & E & 81 & Çankırı & $(+)$ & $(-)$ \\
\hline 16 & $E$ & 45 & Yozgat & $(-)$ & $(+)$ \\
\hline 23 & $E$ & 32 & Samsun & $(-)$ & $(+)$ \\
\hline 56 & $E$ & B & Kayseri & $(-)$ & $(+)$ \\
\hline 71 & K & 31 & Yozgat & $(+)$ & $(+)$ \\
\hline 76 & K & 62 & Yozgat & $(-)$ & $(+)$ \\
\hline 94 & K & 85 & Ordu & $(+)$ & $(+)$ \\
\hline 102 & $E$ & 26 & Mardin & $(-)$ & $(+)$ \\
\hline
\end{tabular}


lenfadenite neden olmaktadır ${ }^{10}$. TB lenfadenit, akciğer dışı organlarda latent kalan basilin, konak direncinin azalması sonucu hayatın herhangi bir devresinde reaktive olması ile gelişmektedir ${ }^{11-13}$. Primer enfeksiyondan yaklaşık 4-12 ay sonra lenf drenajına uygun olarak en sık servikal, mediastinal ve aksiller bölgedeki lenf bezleri tutulmaktadır ${ }^{12-14}$. Servikal TB lenfadenit, akciğer veya başka organ tutulumu olmaksızın tek belirti olabi$\operatorname{lir}^{3,12-14}$. Ayrıca TB lenfadenitte, akciğer tüberkülozunda sık saptanan ateş, gece terlemesi, halsizlik ve kilo kaybı gibi bulgulara daha az sıkıkla rastlanması, tanının gecikmesine neden olmaktadır 3,13-15. Ülkemizdeki verilere göre, AD-TB olgularının oranının yıllar içerisinde arttığı ve TB lenfadenitlerin bu olgular içerisinde \%31.4'lük bir kısmı oluşturduğu görülmektedir².

Tularemi, ülkemizde yeniden güncel hale gelmesine karşın, hastalığın yeni görüldüğü bölgelerde orofarengeal tularemili olgulardaki servikal lenfadenitlerde yeterli mikrobiyolojik incelemenin yapılmaması ve histopatolojik incelemede granülomatöz yangının saptanmasıyla hastalara yanlışıkla TB lenfadenit tanısı konulabilmektedir ${ }^{8}$. Diğer taraftan, farkındalığın artmasıyla birlikte, özellikle tulareminin endemik olduğu bölgelerde servikal lenfadenitlerin ayırıcı tanısında F.tularensis ilk sırada düşünülmeye başlanmıştır.

Bizim çalışmamızda, tularemi salgınları esnasında tularemi lenfadeniti şüphesiyle incelemeye alınan servikal lenf aspiratlarında M.tuberculosis varlığı araştırılmış ve örneklerin \%8.6'sında moleküler ve/veya kültür yöntemiyle pozitiflik tespit edilmiştir. M.tuberculosis pozitif olguların, tulareminin endemik olduğu bölgelerde, tularemi salgınları sırasında tespit edildiği dikkati çekmektedir. Taşbakan ve arkadaşlarının ${ }^{14} 1997-2009$ yılları arasında 694 tüberküloz lenfadeniti olgusunu irdeledikleri çalışmalarında; hastalığın kadınlarda daha sık görüldüğü ve özellikle 20-40 yaş arası bireylerde sık rastlandığı rapor edilmiştir. Bizim çalışmamızda, M.tuberculosis saptanan olguların erkek/kadın oranının 6/3 olduğu ve yaş dağılımının 26-85 yıl arasında değiştiği görülmüş; bu farklıığın olgu sayısının düşük olması ve örneklemin normal toplumu yansıtmamasından kaynaklandığı düşünülmüştür.

Çalışmamızda, örneklerin ikisinde sadece kültür ile, beşinde sadece rtPCR ile ve ikisinde hem kültür hem de rtPCR ile M.tuberculosis pozitifliği saptanmıştır. TB lenfadenitinde basil sayısının az olması ve tutulan dokudan örnek almanın zorluğu nedeniyle, tanının bakteriyolojik olarak doğrulanması zordur $3,14,16$. Yapılan çalışmalarda, TB lenfadenitinde kültür pozitifliği \%10-60 arasında bildirilmektedir ${ }^{3,8,14}$. Bizim çalışmamızda, kültür ve rtPCR yöntemleriyle dokuz olguda M.tuberculosis saptanmakla birlikte, yapılan ulusal ve uluslararası çalışmalar göz önüne alındığında ve bakteriyolojik tanının TB lenfadenitini tespit etmede yetersiz kaldığı varsayıldığında, aslında bakteriyolojik olarak M.tuberculosis negatif saptanan olguların bir kısmının TB lenfadeniti olma olasılığının göz ardı edilmemesi gerektiği düşünülmüştür. Sonuç olarak bu ön çalışmanın verileri, tularemin endemik olduğu bölgelerde tularemi lenfadenitinden şüphelenilen olgularda, TB lenfadenitinin de akılda tutulması gerektiğini ortaya koymakta ve bu olguların eş zamanlı olarak M.tuberculosis yönünden de araştırılmasının uygun olacağını vurgulamaktadır. 


\section{KAYNAKLAR}

1. World Health Organization. Global Tuberculosis Report, 2012. Available at: http://apps.who.int/iris/bitstre am/10665/75938/1/9789241564502_eng.pdf

2. Bozkurt H. Türkiye geneli tüberküloz verileri, s: 47-74. Bozkurt H (ed), Türkiye'de Verem Savaşı 2011 Raporu. 2011, Fersa Ofset, Ankara.

3. Lenci G, Gartenschlager M. Current aspects of lymph node tuberculosis of the neck. Pneumologie 1996; 50(7): 426-8.

4. Fontanilla JM, Barnes A, von Reyn CF. Current diagnosis and management of peripheral tuberculous lymphadenitis. Clin Infect Dis 2011; 53(6): 555-62.

5. Sjostedt A. Tularemia: history, epidemiology, pathogen physiology, and clinical manifestations. Ann $\mathrm{N} \mathrm{Y}$ Acad Sci 2007; 1105: 1-29.

6. Kılıç S. Francisella tularensis ve Türkiye'de tularemi epidemiyolojisine genel bir bakış. FLORA 2010; 15(2): 37-58.

7. World Health Organization. WHO Guidelines on Tularaemia. WHO/CDS/EPR/2007.7. Available at: http:// www.who.int/csr/resources/publications/deliberate/WHO_CDS_EPR_2007_7/en/

8. Karabay O, Kilic S, Gurcan S, et al. Cervical lymphadenitis: tuberculosis or tularaemia? Clin Microbiol Infect 2013; 19(2): 113-7.

9. Ulu-Kılıç A, Kılıç S, Şencan i ve ark. İç Anadolu Bölgesinde Francisella tularensis alt tür halorctica'ya bağlı su kaynaklı bir tularemi salgını. Mikrobiyol Bul 2011; 45(2): 234-47.

10. Asano S. Granulomatous lymphadenitis. J Clin Exp Hematop 2012; 52(1): 1-16.

11. Bass JB, Farer LS, Hopewell PC, et al. Diagnostic standards and classification of tuberculosis. Am Rev Respir Dis 1990; 142(3): 725-35.

12. Karagöz T, Şenol T, Bekçi TT. Tüberküloz lenfadenit. Toraks Derg 2001; 2(1): 74-9.

13. Tatar D, Alptekin S, Coşkunol i, Aydın M. Lenf bezi tüberkülozlu olguların özellikleri. Solunum Hastalıkları Derg 2007; 18(1): 20-5.

14. Taşbakan MS, Pullukçu H, Sipahi OR, Taşbakan MI, Çalık ŞÖ, Yamazhan T. Türkiye'de 1997-2009 yılları arasında yayınlanan 694 tüberküloz lenfadenit olgusunun havuz analiz yöntemi ile değerlendirilmesi. Mikrobiyol Bul 2010; 44(3): 385-93.

15. İnönü H, Köseoğlu D, Pazarlı C ve ark. Bir üniversite hastanesinde takip edilen ekstrapulmoner tüberkülozlu olguların özellikleri. Turk Toraks Derg 2010; 11(4): 167-72.

16. Diagnostic Standards and Classification of Tuberculosis in Adults and Children. This official statement of the American Thoracic Society and the Centers for Disease Control and Prevention was adopted by the ATS Board of Directors, July 1999. This statement was endorsed by the Council of the Infectious Disease Society of America, September 1999. Am J Respir Crit Care Med 2000; 161(4 Pt 1): 1376-95. 